ARTICLE

DOI: $10.1057 /$ s41599-018-0151-3

\title{
Individual liberty and the importance of the concept of the people
}

\author{
Regina Queiroz ${ }^{1}$
}

\begin{abstract}
Through publically agreed laws that correspond to a common set of public restrictions, the 'people as a sovereign body' serves to protect against violations of individual liberty and despotic power. Where no such common body exists, individuals are deprived of this protection. In such cases, individuals must obey without liberty, while those in power command under a state of license. Neoliberal theorists maintain that any common personality, with its corresponding set of public and arbitrary positive and negative restrictions on liberty, undermines individual liberty. Neoliberal theory only allows for private restrictions on liberty. Against these neoliberal assumptions, we argue that rejecting public restrictions on liberty does not promote individual liberty. To the contrary, it creates conditions in which free individuals become servile and political inequality becomes entrenched, where citizens are divided into those who obey and those who command. Tracing the consequences of neoliberalism, we argue that unless we take seriously both the people as a political category and the right to equal and reciprocal coercion, individual liberty will be at risk. The article argues that neoliberalism ultimately leads to the total exclusion of certain citizens under the veil of full liberty. With the vanishing of the people's will comes the utter disappearance of certain citizens, who live in a spontaneous society as if they were stateless or lawless persons. To better understand the connections between the rejection of the concept of the people, private restrictions on liberty and the fostering of the servile citizen, this paper considers the political philosophy of Hayek and Nozick. It also considers key ideas from Locke and Kant-theorists who, despite the differences between their philosophical perspectives, and despite the fact that they both provided crucial inspiration for Hayek's political economy and Nozick's libertarianism, stressed the protective role of the people with regard to individual liberty.
\end{abstract}

\footnotetext{
${ }^{1}$ Universidade Nova de Lisboa, Lisboa, Portugal. Correspondence and requests for materials should be addressed to R.Q. (email: queiroz.regina@gmail.com)
} 


\section{Introduction}

hrough publically agreed laws that correspond to a common set of public restrictions, the 'people as a sovereign body' serves to protect against violations of individual liberty and despotic power (Locke, 1679 (1960); Kant, 1793 (1977)). Where no such common body exists, individuals are deprived of this protection. In such cases, individuals must obey without liberty, while those in power command under a state of license, i.e., a state of unrestricted liberty. Neoliberal theorists maintain that any common personality, with its corresponding set of public restrictions on liberty, undermines individual liberty (Hayek, 1976; Nozick, 1974). Therefore, in addition to promoting the idea of private, atomized individuals and denying the existence of "the people" (Hayek, 1976; Nozick, 1974), neoliberal theory permits only private restrictions (positive and negative) on liberty (Hayek, 1976; Nozick, 1974).

Against this neoliberal assumption (Hayek, 1976; Nozick, 1974), we shall argue that rejecting the concept of the people and public restrictions on liberty while preserving the general law, its protective function, and coercive institutions and instruments for enforcing neoliberal law poses a serious threat to individual liberty and ultimately risks reducing the majority of free individuals to servile-and in some cases lawless-persons.

The literature has already demonstrated the incompatibility between neoliberalism and the notion of the people as a political category and reality (Brown, 2015; Dean, 2008). The impact of neoliberalism's exclusion of the people and its reliance on the concept of publicity without a public has also been demonstrated (Queiroz, 2017). Related to this, the literature has addressed how neoliberalism fosters the development of a docile and disciplined citizenry (Foucault, 2008). Nonetheless, the political consequences of the exclusion of the people and the protective role it plays in the preservation of the political state-namely the transformation of free individuals into servile, and ultimately lawless, persons-has yet to be addressed, in particular from a political-philosophical point of view.

The importance of this issue is clear. There has been much emphasis on the economic nature of neoliberalism, which has obscured the fact that, more than an economic position, neoliberalism is a political outlook and reality (Bruff, 2014). Although neoliberalism has become deeply tied to economics (Hall, 2011; Read, 2009), this is mainly due to the fact that its theoretical understanding of the state as a political institution is made in analogy with the economic market and the subsequent political redefinition of the latter's aims and scope (Foucault, 2008). Thus, without neglecting the significance of neoliberal economic analysis, in shifting the focus to neoliberalism's political character we aim to disclose its political-philosophical foundations and to translate its allegedly purely economic aspects to the political sphere. As we will see, the imposition of fiscal equilibrium, fiscal consolidation, cuts to social security, the privatization of public property, the liberalization of collective bargaining, and the shrinking of pensions (Barro, 2009) are connected not only to the rise of poverty and inequality but also to the transformation of free citizens into dependent and servile persons.

The underlying philosophical principles formulated in Hayek's political economy, political philosophy and legal theory, as well as in Nozick's libertarianism, have spilled over into politics. Although, as empirical studies frequently show, there is always a gap between theoretical statements and practical reality, these principles now provide, at a national and international level, the law's substantive content (Brown, 2015; Gill, 1998; Hall, 2011; Klein, 2007; Overbeek, 1993).

For these reasons, we do not intend to evaluate the "exegetical" value of Hayek's and Nozick's philosophical views (for example Hayek's mistaken reading of Kant's ethical and political philosophy; Gray, 1989). At the same time, we cannot here explore the important material basis of neoliberal ideology, namely concrete neoliberal activities, processes and powerful neoliberal social and political forces, such as multinational corporations (Brown, 2015; Gill, 1998; Hall, 2011; Harvey, 2005; Klein, 2007; Overbeek, 1993). Instead, we aim to show that the philosophical assumptions underlying Hayek's political economy and Nozick's libertarianism allow us to clarify the connection between the exclusion of the people as a political category and neoliberalism's promotion of a servile citizenry.

To better understand this connection, this paper will consider the Lockean and Kantian concepts of the people. Despite the differences between Locke's and Kant's political philosophies (Gray, 1989; Williams, 1994), for both thinkers the people serves the function of protecting individual liberty against despotic power, a condition which is commonly referred to as political obligation under liberty. Hayek and Nozick explicitly refer to the Lockean and Kantian foundations of their views, for example the Kantian universalization test for establishing the validity of the abstract rules of the market state (Hayek, 1976). Nozick's use of the Kantian understanding of the person as an end in itself to justify the rejection of substantive principles of justice (Nozick, 1974) provides an additional reason to consider Locke's and Kant's conceptions of the people in detail.

There are of course important differences between our current social, political and technological context, which is characterized by globalization, and Locke and Kant's modern nation states. We ought also to consider the differences between how we conceive of the people, e.g., whether we define peoples in terms of national commonality (Miller, 2000) or whether we ought to stress the role of democratic politics in creating this sense of political belonging (Habermas, 2008). Equally significant is the fact that, contrary to neoliberalism, Locke's liberalism depends on homo politicus and juridicus rather than homo economicus, which generates significant tensions between his rights-based view and modern views based on interests (Foucault, 2008). Equally, we wish to overlook neither Locke's and Kant's controversial statements and practices, for example Kant's exclusion of non-property-owners from the social contract (Kersting, 1992), nor the limits of Locke's and Kant's theoretical constructions of political personality (Badiou, 2016). The weaknesses of past democracies, expressed in the exclusion of woman from equal citizenship, the existence of slavery, and contemporary populist perversions of democracy, do not entail that we must abandon the ideal of democratic political power, however. The negative aspects of Locke's and Kant's political philosophies should not erase their strong commitment, from a liberal perspective, to the importance of the concept of the people when it comes to protecting individual liberty.

Finally, we do not wish to ignore past conceptions of the people, such as Greco-Roman conceptions, republican conceptions (Cicero, 1999; Habermas, 2000; Rousseau, 1762 (1964)), Marxist conceptions (Badiou, 2016), and other current alternatives. Despite their differences, they share certain features with the liberal approach, such as assigning a protective role to the people. In the face of the political consequences of neoliberalism's exclusion of the people, we should appeal to what Rawls (1993) calls overlapping consensus, i.e., agreement on the people as a political category on different grounds.

The paper is organized as follows. Section 1 provides a brief presentation of the main concepts and neoliberalism's rejection of public restrictions on liberty and the right to equal and reciprocal coercion. In the second section, we show that, contrary to neoliberal assumptions, far from fostering individual liberty, the exclusively private restriction of liberty implies a political distinction between those who obey and those who rule. It also 
entails the division of citizens into those who obey and those who command, where the latter are given unequal protection by the government and thus an unequal share in the public coercive power. Similarly, it involves the introduction of two familiar political categories, originally deployed in neoliberal political society: self-serfdom on the one hand and invisible, voiceless citizenship on the other. At the end of the paper, we provide a brief account of the protective role of the people as a political body when it comes to individual liberty. We show that by ensuring the equal and reciprocal right of coercion, the people as a body protects individual liberty.

\section{The people vs. the private coercion of liberty under neoliberalism}

As an imprecise and nebulous concept, there is no single "pure" form of neoliberalism. Instead, there are varied articulations that make up an extraordinarily messy amalgam of neoliberal ideas and policies at multiple sites (Latin America, Europe, China; Harvey, 2005), on multiple scales (national, international, transnational, global; Brown, 2015; Hall, 2011; Klein, 2007; Overbeek, 1993), and within the many versions of the welfare state (Kus, 2006). Additionally, according to England and Ward's (2016) taxonomy, neoliberalism can be thought of as a form of statecraft that promotes the reduction of government spending while increasing economic completion (Mudge, 2008), or as a form of governmentality that comprises social, cultural and economic practices that constitute new spaces and subjects (Foucault, 2008). In addition, neoliberalism can be seen as a reaction to the disenchantment identified by Weber, (1978) following the rise of bureaucracy. Neoliberalism expresses a kind of re-enchantment with the exclusively individual rational actor, who claims a nonalienable space of liberty against a bureaucratic "iron cage". Although some see neoliberalism as a privatized version of economic and bureaucratic despotism (Lorenz, 2012) or as a totalizing global bureaucracy (Hickel, 2016), this re-enchantment can explain the enthusiastic endorsement of neoliberal principles by a wide spectrum of political and ideological forces, for example by the Labour party under Blair in Great Britain, the SPD under Schröder in Germany, and followers of Pinochet in Chile.

Finally, neoliberalism has been viewed as a conception of the world, or a "total view of reality" (Ramey, 2015, p. 3), which is meant to be applied to the political realm and the entirety of human existence. Integrated into common sense, its main ideas stem from the everyday experience of buying and selling commodities on the market, a model that is then transferred to society. As a total view of reality, neoliberalism entails "a new understanding of human nature and social existence [and] the way in which human beings make themselves and are made subjects" (Read, 2009, p. 28; see also Foucault, 2008).

While acknowledging the disparate criteria for defining and assessing neoliberal theory and practice, we maintain that neoliberalism is a political outlook and reality (Bruff, 2014) which has evolved in part in accordance with the framework of the theoretical premises of Hayek's, (1976) political economy and Nozick's, (1974) philosophical libertarianism. For instance, neoliberal theoretical principles now provide, at a national and international level, substantive content to political constitutions (McCluskey, 2003), the establishment of laws governing the executive (Foucault, 2008; Read, 2009), and the reformulation of laws governing citizens (LeBaron, 2008; McCluskey, 2003; Supiot, 2013, p. 141; Wacquant, 1999). They also shape our comprehension of the world and ourselves (for example the reduction of the citizen to an entrepreneur; Peters, 2016). Thus, although there is no purely neoliberal society or state-neoliberalism evolves within various societies in different ways (see Harvey, 2005)- neoliberal political theory allows us to clarify the political premises that underlie the disparate versions of neoliberalism.

In preserving the political state, neoliberal individualistic premises do not accommodate the notion of the people, i.e., the citizens of a given political community or a unitary political body (demos or populus), understood as an ultimate intentional lawmaker or sovereign (Locke, 1679 (1960)). The category of the people is a political criterion, which refers to the main act of the people's sovereignty: their giving law to themselves, in the form of rights and duties (Locke, 1679 (1960); Kant, 1793 (1977); Rousseau, 1762 (1964); Sieyes, 1789 (1989)). Putting to the side the relationship between political (Dahl, 1998; Rawls, 1999; Sieyes, 1789 [1989]) and ethnic (Habermas, 2000, 2008) criteria, this act unifies individuals who belong to different ethnicities, cultures, and linguistic traditions. The results of this act are the civic, political and social human rights which have traditionally been the privileged content of the laws of peoples (Locke, 1679 (1960); Kant, 1793 (1977); Marshall, 1950; Rawls, 1971, 1999).

It is true that women and slaves have historically been excluded from the category of the people. It is also undeniable that such exclusion has not been completely overcome and that new categories of exclusion have emerged, such as ageism and digital exclusion. Important political differences within peoples on the axes of class (Badiou, 2016), gender (Elstain, 1981), race (Wilson, 2012), and citizenship remain. Nonetheless, the content of the laws of peoples has provided political criteria for denouncing and reducing, if not eliminating, these exclusions (e.g., in South Africa with the end of Apartheid).

Despite the complexity of the relationship between the state and the sovereignty of the people (Habermas, 2008), the political criterion stresses the subordination of the state to the sovereign people. It also points to the reformulation of the powers of states, "specifying that their legislators must not make certain laws, or must advance certain objectives" (Pyke, 2001, p. 205). For example, instead of exclusively preserving peace or economic and financial efficiency, states ought to ensure the well-being of their citizens. In the absence of such restrictions, the overestimation of states' economic goals (such as low inflation, the removal of trade barriers and foreign currency control, and minimal regulation of the economic labor market) can result in the undermining of welfare at the national (Brodie, 2007) and international level (Beck, 2002).

Some argue that nation states provide a criterion for determining political belonging (Miller, 2000). However, the political criterion points to the fact that one's relation to a given nation state should be based on common laws, not ethnic or cultural differences. Rawls's, (1999) liberal approach to international relationships argues against cosmopolitan principles of justice that are blind to the political (and moral) differences between peoples, for example the difference between liberal and decent peoples, where the former is based on an individualistic tradition and the latter on a 'corporative' tradition. Despite the perils of extending sovereign power to the global order (e.g., populism) and people's incomprehension of the full import of economic and political factors, this order should respect the sovereignty of peoples. Neoliberalism's "global policy of boundary removal" (Beck, 2002, p. 78) undermines the sovereignty of the people (Beck, 2002; Overbeek, 1993). Indeed, the growth of international law affects domestic legal systems, limiting the political choices of legislators and voters, and competition in globalized markets does not allow nations or states to regulate their industries and workplaces. As Hickel notes, for example, financial liberalization creates conditions under which "investors can conduct momentby-moment referendums on decisions made by voters and governments around the world, bestowing their favor on countries that facilitate profit maximization while punishing those that 
prioritize other concerns, like decent wages" (Hickel, 2016, p. 147).

Peoples are the main 'actors' in the international and global arena, their sovereignty, along with their constitutional power, cannot dispense with common laws. Despite the crucial issue of the existence of mechanisms for enforcing those laws, human rights such as freedom from slavery and serfdom, mass murder and genocide can provide their content (Rawls, 1999). Although the political manipulation of the law by national-hegemonic principles (Beck, 2002) and the enforcement issue (Lane, et al. 2006) must be kept in mind, the human rights approach is relevant to Locke's and Kant's concepts of the people. There is a difference between the national order underlying Locke's and Kant's approaches to the sovereignty of the people and our contemporary international and global order, human rights can create, at the national, international and global level, a sense of political belonging (Habermas, 2008; Lane et al. 2006; Rawls, 1999). As political criteria, human rights preclude resolving persistent political conflicts on the basis of ethnic or national criteria, as occurs with populism and nationalism, respectively.

Given this intricate theoretical framework, as well as the complexity of the notion of a sovereign people (Butler, 2016; Morgan, 1988; Morris, 2000), we stress that whatever its scope, the sovereign people plays a protective role with regard to citizens' liberties in general and against despotic power in particular (Locke, 1679 (1960); Kant, 1793 (1977)). Locke, (1679 (1960)) and Kant, (1793 ([1977)) assume that the sovereign people guarantees individual liberty in any human association. Both thinkers hold both that human associations (or societies) of free persons cannot deny the political facts of power, obedience and command (Locke, 1679 ([1960); Kant, 1793 (1977)) and that, in natural (rather than political) conditions, individual liberty is unrestricted. Since in the state of nature it is possible for one to obey unconditionally, having only duties, while the other in turn commands unconditionally, having only rights, the unrestrictedly obedient enjoy no protection against unrestricted power, at least concerning their right to life (Locke, 1679 ([1960); Kant, 1793 (1977)). From this perspective, i.e., from the perspective of individual liberty, the practical (as opposed to theoretical) challenge consists in conceiving of an alliance between individuals that does not undermine their individual liberty. The people as a political body expresses precisely this alliance: an inter-protective construction that replaces the state of unconditional obedience and command.

Following the controversial model of the contractual act (Gough, 1957), individuals transfer to the political power their unrestricted natural right to liberty. This transfer transforms them into "one people, one body politic" (Locke, 1679 (1960), II, p. 89). As members of the people, individuals equally consent to restricting their liberty under a political order and to preserving an equal coercive power, which prevents them from being reduced to servile persons and, correlatively, prevents any one of their numbers from becoming a despotic lord (Locke, 1679 (1960); Kant, 1793 (1977)). As such, they establish public law-a system of laws for a people, i.e., an aggregate of human beings, or an aggregate of peoples (Kant, 1793 (1977)) —-which allows them to live in a lawful state.

Through public law, i.e., laws based on their will, the people provides to each individual a unique set of liberties with regard to the use of material goods and imposes on each a unique set of restrictions (Locke, 1679 (1960); Kant, 1793 (1977)). When pursuing their personal well-being, as members of the people, individuals cannot ignore this common set of rights and restrictions. When pursuing their well-being, individuals are also, but not exclusively, bound to demands that are independent of their individual interests.
Public vs. private law. Neoliberal theory and practice does not preclude a common law (Buchanan and Tullock, 1962; Hayek, 1976). The common law that it involves is not, however, a law of the people that provides liberties (rights) and imposes a unique set of restrictions (Buchanan and Tullock, 1962; Hayek, 1976; Nozick, 1974). Indeed, neoliberal political theory does not allow for the transformation of individual personalities or isolated natural selves into a collective or single public, viewed as the ultimate intentional lawmaker, which is the model we find, for example, in Locke, (1679 (1960)), Kant, (1793 (1977)), and Rawls, (1971). In Nozick's political theory, when private persons establish a contract to govern their use of the possessions over which they have a private right (Nozick, 1974) - this conception of rights includes both material possessions and natural talentsthey are always separate units that remain separate even when they form associations (Nozick, 1974). They do not constitute a common person subject to common legislation that defines and regulates political authority and applies equally to all persons. This mirrors Hayek's suggestion that it is absurd to speak of rights as claims which no one has an obligation to obey, or even to exercise (Hayek, 1976). On this view, human rights result from personal interests, and persons cannot be bound to claims that are independent of their private interests. These claims presuppose a public obligation (or the possibility of coercion), which involves a political organization in which decision-makers act as collective agents: as members of a people rather than individuals. Yet on the neoliberal conception, collective deliberation of this sort limits, and even undermines, individual liberty (Buchanan and Tullock, 1962; Hayek, 1976; Nozick, 1974), leading to oppression (Buchanan and Tullock, 1962), if not to serfdom (Hayek, 1960).

Viewed from the neoliberal standpoint as a meaningless or mystical political category (Buchanan and Tullock, 1962)_"a fairy tale" (Hayek, 1960, p. 35)-the political deliberation of the people imposes obligations on individuals, undermining their liberty and well-being. The people as a political body is based on the supposition that someone (the people) can intentionally prevent or promote certain results, which, via end-rules, guiding organizations can compel individuals to attain. In addition to their "epistemological impossibility" (Gray, 1993, p. 38), however -individuals' multiple interactions produce unpredictable and unforeseen results-end-rules interfere with individual liberty and worsen the positions of all (Hayek, 1976), in particular those who are better off (Nozick, 1974). Interference (or intervention), which is "by definition an [...] act of coercion" (Hayek, 1976, p. 129), is "properly applied to specific orders [that aim] at particular results" (Hayek, 1976, p. 128). Moreover, interference and intervention occurs "if we changed the position of any particular part in a manner which is not in accord with the general principle of its operation" (Hayek, 1976, p. 128).

The general principle of the operation of the spontaneous society is negative liberty, or "the absence of a particular obstacle -coercion by other men" (Hayek, 1960, p. 18) in one's pursuit of maximal individual well-being. Requiring that the situation of the less well off be improved via the principle of the equality of opportunity, for example, involves restricting individual liberty in order to improve the situations of others (Hayek, 1960, 1976; Nozick, 1974). This improvement is thought to be unacceptable because, in addition to presupposing that we can determine the circumstances under which individuals pursue their aims, binding persons to claims that are independent of their private interests constitutes an interference in their liberty (Hayek, 1976). Even if it is admitted that the principle of equal opportunity entails neither complete control over the circumstances in which individuals pursue their well-being (Rawls, 1971), nor equality of results (Rawls, 1971), nor the worsening of the position of the 
better-off (see Rawls's principle of difference, Rawls, 1971), the fact that it involves changing the positions of individuals via a public rule means that it constitutes the imposition of an illegitimate obligation on individuals (Hayek, 1960; 1976; Nozick, 1974). The public law limits the overall sum of well-being-the greater the privatization, the greater the well-being-and restricts the unlimited intensification of individuals' purely private interests (see Hayek's, (1976) and Nozick's, (1974) criticism of the utilitarian and Rawlsian theories of social justice). "Inconsistent" (Hayek, 1976, p. 129) with individual liberties from the perspective of negative liberty and with the unlimited intensification of individuals' purely private interests, public rules are transformed into private rules (commands or end-rules).

On the neoliberal view, the pursuit of individual ends ought to be based on historical principles (Nozick, 1974) or Hayek's abstract rules, which only set out the procedures for acquiring and preserving individual well-being and which do not refer to a common purpose, such as social justice: "Freedom under the law rests on the contention that when we obey laws, in the sense of general abstract rules irrespective of their application to us; we are not subject to another man's will and are therefore free" (Hayek, 1960 , p. 11). Under this negative conception of liberty, abstract rules allow for the improvement of "the chances of all in the pursuit of their aims"; they are therefore truly public rules:

To regard only the public law as serving general welfare and the private law as protecting only the selfish interests of the individuals would be a complete inversion of the truth: it is an error to believe that only actions, which deliberately aim at common purposes, serve common needs. The fact is rather that what the spontaneous order of society provides for us is more important for everyone, and therefore for the general welfare, than most of the particular services which the organization of government can provide, excepting only the security provided by the enforcement of the rules of just conduct. (Hayek, 1960, p. 132 emphasis added).

Neoliberal "public" rules are therefore abstract rules that exclude common concern. Organizations "sanction" the rights resulting from individuals' interactions under abstract rules (Hayek, 1976). This means not only that governments ought to mirror that order-they cannot provide any rights of themselves - but also that the judicial system ought to be redesigned to fit with the Great Society. Indeed, Hayek critiques the enslavement of law by "false economics" (Hayek, 1960, p. 67), i.e., economics that are dependent on the existence of public goods, and "prophetically" foresees the disappearance of this law in the spontaneous society (Hayek, 1960). Other neoliberal theorists have conceived of the neoliberal impact on law in similar terms, envisaging a legal system based on "true neoliberal economics", which transforms the law into a bond "oblig[ing] one party to behave according to the expectations of the other" (Supiot, 2013, p. 141; see also LeBaron, 2008; McCluskey, 2003; Wacquant, 1999).

This model cannot accommodate the idea of a public person, the people, to whom individuals belong; indeed, the role of ultimate intentional lawmaker is taken from the people and given to the spontaneous order, the Great or Open Society. Understood in analogy with the economic market, and equating to abstract rules applied to "an unknown number of future instances" (Hayek, 1976: 35), this spontaneous order constitutes the sovereign lawmaker (Queiroz, 2017).

Neoliberal political intervention under private law. Under the negative conception of liberty, individual freedom is compatible with impediments and constraints (liberty is not bare license, which ultimately undermines negative liberty; Berlin, 1958). Abstract rules allow for private restrictions on liberty, and neoliberal governmental organizations ought to ensure that any restrictions on liberty are limited to the private realm. Neoliberal theorists do not understand this protection as a form of intervention or interference, however. Hayek, (1960), for example, argues for this notion by establishing a distinction between repairing and intervening. When a person oils a clock, they are merely repairing it, securing the conditions required for its proper functioning. In turn, when a person changes "the position of any particular part in a manner which is not in accord with the general principle of its operation" (Hayek, 1976, p. 128), for example by shifting the clock's hands, this counts as intervention or interference. In other words, just as oiling a clock provides the conditions required for its proper functioning, so governmental protection of the private scope of restrictions on liberty allows for the proper functioning of the Great Society. Both merely create the conditions under which individual wellbeing can be maintained, if not increased. In turn, just as shifting the hands of a clock is not in accord with the general principle of the clock's operation, public rules, which impose illegitimate obligations on individuals, constitute an intervention into the functioning of the spontaneous society.

When establishing the particular character of organizations' rules, and excluding "the security provided by the enforcement of the rules of the just conduct" (Hayek, 1960, p. 132), this enforcement means that neoliberal politicians intentionally intervene, but only to prevent the auto-destruction of the "mechanism" itself. They permanently adjust the rules to the neoliberal common law.

Consider a situation in which two people, $\mathrm{A}$ and $\mathrm{B}$, are involved in cooperative activity and in which both establish a common rule to safeguard the maximization of their interests. Under this rule, A and B both contribute to the maximization of their own well-being. Although it accepts the interdependence of individuals when pursuing their personal well-being, neoliberal reparation does not allow for a common right to the results of that cooperative interdependence (Hayek, 1976; Nozick, 1974). In denying the existence of a public person, a public will, and in ultimately challenging the idea that there is a common right to a share in the total well-being that results from the contributions of all, neoliberalism not only allows, but also requires, that one party has a claim to the exclusively private enjoyment of the benefits of their mutual relationship. Accordingly, neoliberal repair (a metaphor for neoliberal government) ought to remove public law, which allows for the common right to well-being, and should replace it with private law. In this way, the proper functioning of the Great Society-which permits the unrestricted preservation and increasing of individuals' private wellbeing — can be reestablished. The resulting intensification of poverty and inequality (Greer, 2014; Matsaganis and Leventi 2014; Stiglitz, 2013), the diminishing security of employment and income (Clayton and Pontusson, 1998; Stiglitz, 2013), and growing authoritarianism (Brown, 2015; Bruff, 2014; Kreuder-Sonnen and Zangl, 2015; Orphanides, 2014; Schmidt and Thatcher, 2014) are not problems in themselves. To the contrary, to the extent that it undermines individual liberty, any attempt to redress these effects violates the law of the neoliberal state, which, Hayek would say, is based on "true economics". Accordingly, when choosing between the intensification of poverty and inequality and allegiance to the right of non-interference, non-interference must prevail, thus preventing political and social action to reduce (or compensate for) poverty and inequality. Notwithstanding the underlying theoretical debate on the legitimacy and justice of the acquisition of private rights (Hayek, 1976; Marx, 2000; Nozick, 1974; Rawls, 1971, 1993), enforcing the rules of the Open Society deprives one 
part of that society of the right to their well-being and to their contribution to the general well-being. Under the neoliberal model of government and law, certain citizens are deprived of the right to enjoy the public goods that result from their collective activity, while others enjoy a private right to goods that result from the contribution of all. Since those who benefit are not able to acknowledge the contribution of others, they erase it and privatize the public law. This privatization shows that the neoliberal trinity of privatization, flexibilization and deregulation ultimately results from the original privatization of the public or common law.

\section{Private restrictions on liberty and coercive positive liberty}

Aside from the controversy concerning the epistemological value of the distinction between negative and positive liberty (Berlin, 1958 [1997]; Gray, 1993; Rawls, 1971, 1993; Taylor, 1979), theoretical disagreement about their meanings (Taylor, 1979), and the caricatures by which they are often understood (e.g., positive liberty as a form of being "forced-to-be-free"; Taylor, 1979), governmental protection of private restrictions on liberty under neoliberalism shows that neoliberal political theory does not dispense with the coercive feature of positive liberty (see Gray, 1989 for a reading of Hayekian freedom as more than merely negative).

This not a negligible issue; neoliberal political philosophers establish a relationship between the main act of the people's sovereignty, or its constitutional power-establishing a public law that provides to each person a unique set of liberties with regard to the use of material goods and imposes on each a unique set of restrictions - and the violation of individual liberty (Hayek, 1976; Nozick, 1974). The replacement of the people's sovereignty with the spontaneous order is thought to be justifiable because "when we obey laws, in the sense of general abstract rules irrespective of their application to us, we are not subject to another man's will and are therefore free" (Hayek, 1960, p. 11). When arguing against the oppressive nature of the rules that issue from the people, neoliberalism relies on the positive meaning of liberty (freedom to be one's own "master"; Berlin, 1958 (1997)). A private right to a good that results from the (perhaps unequal) contribution of all constitutes a coercive act of positive liberty - "coercing others for their own sake, in their, not my, interest" (Berlin, 1958 (1997), p. 397). Similarly, the imposition of that right on society as a whole through legislation, including those who have been deprived of their well-being, also constitutes positive coercion. Citizens who are deprived of their well-being must simply accept the neoliberal diktat, i.e., the transference of their well-being to the few (Stiglitz, 2013). In a paternalistic wayaccording to Berlin, (1958 (1997)), positive liberty is always paternalistic in some sense-neoliberal politicians argue that there is no alternative (TINA) to neoliberal political legislation (the government knows best). Consequently, under the veil of state juridical and political violence, neoliberal politicians present governmental rules as an ultimatum, precluding consent, i.e., forcing individuals to give up their political right to challenge that deprivation (see the political meaning of TINA, Queiroz 2016; Queiroz 2017). The rejection of all public right, i.e., the exclusion of peoples, introduces into the core of the theory (and its practice) the despotic feature that neoliberalism attributes to the general will. In other words, the neoliberal political order mirrors the despotic nature that neoliberals attribute to the meaningless or mystical general will (Buchanan and Tullock, 1962).

The neoliberal ultimatum not only protects those citizens who apparently do not need the state's intervention but also ensures that the law only protects their interests (which constitutes the privatization of legal protection). Neoliberal theorists understand public rules as means of protection, as if private interests were not highly dependent on law. Indeed, Nozick's distinction between 'public', "paternalistically regulated" citizens (Nozick, 1974, p. 14) and free citizens, who dispense with state intervention, obscures the existence of private, "paternalistically regulated" citizens. These citizens are protected by the reparations of neoliberal "public" law. In addition, however, rather than accepting the collective protective scope of the law, they demand a monopoly on it. Although neoliberalism casts them as utterly independent actors-lone Robinson Crusoes-they are highly dependent not only on the contributions of others for their well-being but also on the positive law. This shows that unless there is a common law to prevent others from interfering with one's liberty and to provide certain means, negative liberty is an empty claim.

Insofar as the protective function of the government and the positive law include both legislative and coercive power, instead of coercing others for one's own sake, neoliberal positive liberty allows private individuals to impose, without consent, public restrictions for the sake of their private interests. Neoliberal positive liberty thus leads to the establishment of legal and political inequality: some command without consent, i.e., without restriction, while others obey without consent, i.e., without liberty. Ultimately, making use of the benefits of negative liberty depends on the (political) attribution to individuals of certain legal and political statuses, under which they can make use of their liberty.

Moreover, the positive liberty that underlies the spontaneous order not only deprives certain citizens of their share of the general well-being but also leaves no room to claim a right against that deprivation. Besides protecting negative liberty in the maximization of individuals' well-being, this order does not provide any concrete rights. Hayek explicitly says that it "is meaningless to speak of a right in the sense of a claim on the spontaneous order" (Hayek, 1960, p. 102, II). Indeed, although framed by abstract rules, rights are always obtained under particular circumstances, i.e., in terms of differences between "individuals", for example natural and social talents (Hayek, 1976; Nozick, 1974). Despite the interdependence of all individuals, individuals always remain separate unities and are thus deprived of the right to claim a common share of the fruits of their relationships-as if belonging to a common body entailed personal indifference and the abandonment of private interests. Accordingly, if the Great Society, which replaces the will of the people, does not provide rights to citizens, and if those citizens do not obtain them from their private interactions, it is meaningless to claim such a right or to complain that such a right has been denied them. There is nothing to claim or to complain about. In other words, where there are no rights, there can be no deprivation of rights.

Even if individuals wish to complain about the deprivation of their rights, the neoliberal state-which considers such rights imaginary, fictitious, mystical-does not contain institutions that can address such complaints. Under the neoliberal state, both the people and public institutions vanish into thin air. As Beck stresses with regard to neoliberal globalization, neoliberalism is the power of Nobody (Beck 2002). Alluding to Odysseus's clever escape from the cyclops Polyphemus in the Odyssey (Homer, 1996, 9, pp. 414-455), Beck suggests that the Nobody created under neoliberalism does not establish, protect or enforce equal individual rights. Even though Nozick (unlike Hayek) accepts the existence of natural rights and liberties, his rejection of a public person and public restrictions shows that the assumption of natural rights does not guarantee their enjoyment. In other words, when the will of the people becomes a mirage, individuals' natural rights are also rendered illusory, as the neoliberal spontaneous society illustrates. Accordingly, instead of allowing for the "creat(ion of) conditions likely to improve the chances of all in the pursuit of their aims" (Hayek, 1976, p. 2), private 
restrictions on liberty deprive certain citizens of the chance to pursue their aims (Brown, 2015; Gill, 1998; Hall, 2011; Klein, 2007; Overbeek, 1993; Stiglitz, 2013, 2016). Instead of protecting individual liberty, the rejection of the "fairy tale" of the people allows for the emergence of two familiar political statuses, originally deployed in neoliberal political society: those who live under free self-serfdom on the one hand and the invisible and voiceless on the other.

Free self-serfdom and voiceless persons. A free serf is someone who, although deprived of political protection-whether this is understood as it was in the medieval era (Bloch, 1961), which made a distinction between the protector and the protected, or as it was understood in the liberal tradition (Locke, 1679 (1960); Kant, 1793 (1977)), in which each person is simultaneously protector and protected-can still satisfy their bodily needs through selling themselves or their labor. Neoliberal private restrictions on liberty cannot override the unrestricted autocratic deliberation of those who, in the absence of public law, can freely renounce their liberty in situations of extreme need, thus voluntarily enslaving themselves. The rejection of a public limit to individual liberty, along with the overlapping of public law and private interests, allows for unrestricted orders and, correlatively, for obedience without liberty (on work precariousness see Gill and Pratt, 2008; on work conditions in sweat shops, see Bales 1999). Consequently, neoliberal political theory and practice allow for the creation of a situation in which some citizens (serfs) only obey while others (lords) only command.

One may argue that despite social and economic differences, along with their non-negligible impact on individual liberty (Marx 2000; Rawls, 1971), neoliberalism's Great or Open Society is not compatible with serfdom. Regardless of the lack of clear political criteria for defining an individual's legal and political status (Bloch, 1961), human relationships have evolved under conditions of legal and political inequality (for example the superior free person vs. the inferior serf or vassal). This legal and political inequality is at work, for example, in systems where lords offer protection in exchange for total obedience (on the part of serfs and vassals) (Bloch, 1961). From the perspective of neoliberal theory, we are all equal: neoliberal society does not contain legal or political inequality and does not divide citizens into those who are superior and those who are inferior. It also does not include "protective relationships" or juridical and political obligations. To be at the disposal of someone else who can do whatever they please and to whom one owes unrestricted obedience entails neither that one has an inferior legal status nor that the political relationship at stake is one of a superior to an inferior. Persons have the same legal constitutional status (they all are seen as equally free), and all are equally entitled to pursue their private interests. Even if people sell themselves, this concerns the private restriction of liberty from the perspective of neoliberalism and does not conflict with the conditions required for the proper functioning of the spontaneous order, i.e., with individuals' private liberty. Still, the private scope of individuals' mutual service-the forbidding of serving others for the sake of those others' well-being-does not prevent a person's serving another as a means of ensuring their own private wellbeing, in which case it would not be appropriate to understand their relationship in terms of servant and seignior.

Besides entailing what is known in political philosophy as the liberty of slaves, i.e., the liberty of choosing either to comply with the orders of the master or to be beaten to death, the privatization of the well-being that results from individuals' cooperation is based on the coercive restriction of liberty, under which some obey without liberty and others command without restriction.
Thus, even if in neoliberal spontaneous societies people are not assigned explicitly different political statuses, which entail different political rights and duties, neoliberal political society does not prevent people from becoming servile or, correlatively, from becoming despotic. This fact reveals the extent to which neoliberalism entails a dangerous process of what some authors have called refeudalization (Supiot, 2013; Szalai, 2017), full analysis of which deserves examination of its own.

Nevertheless, when obeying without liberty, if citizens fail to acquire their rights they risk becoming something less than a free serf, i.e., a free excluded citizen. A free excluded citizen is a citizen who lives in a free society without having the personal, social or institutional resources to make use of their own liberty. When the neoliberal spontaneous order does not provide any concrete rights, and when another's wellbeing has no bearing on one's own, one is unrestrictedly free to pursue one's own wellbeing even to the detriment of others unilaterally (the fully alienated person can be thrown away). In this case, voiceless and invisible citizens can only enjoy purely negative liberty, in the absence of the personal, social and institutional resources with which they might otherwise achieve well-being. Neoliberalism also entails the continuous risk of passing from servile (or docile) citizenship into lawless personhood. As such, individuals' social existence is excluded from the neoliberal subjectivation procedure itself (in which human beings make themselves and are made subjects, Foucault, 2008).

Neoliberalism does not reduce to fostering the entrenchment of political inequality: the division of citizens into those who obey and those who command. It also does not merely imply a situation in which some are protected by the state while others are not, where private interests have a monopoly on legal protection and rights while others are denied political protection and only have duties (on work precariousness see Gill and Pratt, 2008). Similarly, it does not exclusively entail political arbitrariness; the private reduction of the "public" law allows for the unilateral institution of the rules (or their revocation). Ultimately, neoliberalism risks leading to the total exclusion of some citizens under the veil of full liberty. The vanishing of the will of the people results in the invisibility of certain kinds of people, who are then forced to live in the spontaneous society as if they were stateless or lawless persons.

It is true that under the distinction between neoliberal theoretical premises and neo-liberal practice individuals' lack of protection does not correspond to these extreme cases. There is a distinction between neoliberal theoretical premises and neoliberal governmental laws within the many versions of the welfare state, for example neoliberalism's reshaping of previous (welfare) state policies along neoliberal lines (Kus, 2006). Neoliberalism has retained some of the elements of that state (such as the protection of the rights of the most vulnerable), although these elements have been reshaped by the market approach to social welfare (Hartman, 2005; MacLeavy, 2016). On this basis, neoliberal officials have assigned public goods and services to private market providers, redesigning social programs to address the needs of neoliberal labor markets rather than personal wellbeing and establishing partnerships between the state and the private sector (Brodie, 2007).

Moreover, some argue that neoliberalism's market approach to social welfare was an attempt to overcome certain economic and social difficulties of the welfare state. For example, economic internationalization has affected the competitive viability of the welfare state (Boyer and Drache, 1996; Rhodes, 1996). Also, the expansion of the state weakened intermediate groups and jeopardized individual liberties, subjecting citizens to increasing bureaucratic controls (Alber, 1988). We shall not 
dwell on a full analysis of these developments. The neoliberal market approach is, however, incompatible with the very idea of a welfare state. Indeed, despite the differences between the socialist, conservative and liberal versions of that state (EspingAndersen, 1990), welfare states protect social rights, such as the right to education and health, and therefore provide social policies to enforce them (Marshall, 1950; Esping-Andersen, 1990), such that " $[t]$ he provided service, not the purchased service, becomes the norm of the social welfare" (Marshall, 1950, p. 309). Moreover, the functioning of the welfare state requires the contribution of fellow citizens (Marshall, 1950; Esping-Andersen, 1990). By contrast, the market approach rejects in principle all social rights, such as the right to education and health, and requires that individual welfare be an exclusively private enterprise (Brodie, 2007; MacLeavy, 2016). Instead of being provided, such services ought to be purchased (Brodie, 2007; MacLeavy, 2016).

Moreover, if the economic market only identifies solvable needs, and if individuals cannot signal their lack of resources, the neoliberal welfare state cannot prevent individuals who have been deprived of their rights from becoming invisible, along with the resulting institutionalized insecurity (Brodie, 2007), intensified poverty and inequality, and diminishing of security of employment and income for many wage earners (Clayton and Pontusson, 1998; Stiglitz, 2013). If the spontaneous society and its governments do not provide any rights, and if individuals do not acquire them in the economic market, there is no reason to claim such rights (including social rights). In this case, neoliberal social welfare reduces to charity (Clayton and Pontusson, 1998; Raddon, 2008; Mendes, 2003). Under this reduction, neoliberal theory fosters individuals' dependence on the private goodwill of citizens who, after legislating with their own interests in mind, and after denying others the right to enjoy the fruits of their own contributions, then establish government spending as a "free lunch" of sorts (all the while paradoxically arguing that "government spending is no free lunch" (Barro, 2009); see Nozick's, (1974) defense of charity)). The neoliberal conception of welfare also shows how neoliberal theory and practice do not prevent the subordination of certain individuals to nonconsensual external mastery.

Neoliberalism is equally committed to state retrenchment or permanent austerity (Whiteside, 2016). By requiring fiscal consolidation, cuts to social security, the privatization of public property, the liberalization of collective bargaining, and the shrinking of pensions (Barro, 2009), austerity not only undermines all attempts to establish social security but also challenges the liberal and democratic basis of society. First, neoliberal austerity neglects people's well-being. A Portuguese neo-liberal politician declared in 2013 that even if under austerity measures the well-being of the people had worsened, the country was better off $^{1}$. The fact that neo-liberal policies have improved the state market is more relevant than the fact that the Portuguese people have been neglected and severely harmed (Legido-Quigley et al. 2016).

Second, neoliberalism excludes in principle the will of the people, i.e., it obliges citizens to obey private laws to which they have not consented. Consequently, it excludes citizens' rejection of its harmful effects, such as poverty and inequality, and rejects all appeals to alternative policies. Following the political referendum of 2015, for example, where the people voted against neoliberal politics of austerity ${ }^{2}$, the Greek government nonetheless imposed a third harsh and austere economic program ${ }^{3}$.

Accordingly, neoliberal political principles, embedded in austerity policies, cannot prevent certain citizens from becoming invisible and voiceless citizens, i.e., Nobodies. As voiceless citizens, their preferences can only be registered through illiberal and antidemocratic channels, such as populism. Only following the election of US President Trump did the deteriorating life conditions of American citizens living in the rust belt states of Michigan, Pennsylvania and Wisconsin become widely known (Walley, 2017). Treated as nothing, and having becoming Nobodies, these citizens face the oppressive and violent institutional neoliberal Nobody, with its no less violent and oppressive political body.

The rise of populism. There is a lack of consensus on the definition of populism (Collier, 2001). It can, however, be described as an organizational or a strategic approach (Weyland, 2001) and ideology (Freeden, 2016; MacRae, 1969; Mudde, 2013; Mudde and Kaltwasser, 2013). The organizational perspective of populism stresses the importance of the personal leader, who bases his or her power on direct, unmediated, and institutionalized relationships with unorganized followers (Weyland, 2001). In turn, as an ideology, i.e., a set of beliefs, values, attitudes, and ideas, populism combines (not always coherently and clearly) political, economic, social, moral, and cultural features with several characteristics that appear together, such as emphasis on the leader's charisma: "the populist can demand the highest principles in the behavior, moral and political, of others while being absolved him or herself from such standards" (MacRae, 1969, p. 158). Beyond these features, however, and despite the fact that the concept of the "pure" people and the corrupted elite can be framed in different ways (Canovan, 1999), the pure and homogenous people and the corrupt and homogenous elites are core concepts that underlie populist ideology (Mudde, 2004).

Since neo-liberal officials do not consider citizens' and peoples' political claims and are not entitled to address the political, economic, and social consequences of their policies, the perception that neo-liberal politicians are corrupt elites has been on the increase (Mudde and Kaltwasser, 2013). This has helped populist leaders to replace neo-liberal politicians, allowing populism to fill the emptiness that has resulted from the failure of those in power to address the people's claims.

Although the relationship between neoliberalism and populism deserves its own examination, the exclusion of the people, along with the right to reciprocal coercion, is a point of tacit agreement between neoliberalism and anti-liberal, anti-democratic political forces (Weyland, 1999). Populist leaders have employed modern, rational models of economic liberalism - such as fiscal consolidation, cuts to social security, the privatization of public property, the liberalization of collective bargaining, and the shrinking of pensions to undermine intermediary associations, entrenched bureaucrats and rival politicians who seek to restrict their personal latitude, to attack influential interest groups, politicians, and bureaucrats, and to combat the serious crises in Latin America and Eastern Europe in the 1980s (Weyland, 1999). In turn, neoliberal experts use populist attacks on special interests to combat state interventionism and view the rise of new political forces, including populists, as crucial for determined market reform (Weyland, 1999). We therefore ought to be careful not to criticize neoliberal authoritarianism while neglecting the hidden powers that secretly support neoliberalism's disdain for the people, such as mafias (Schneider and Schneider, 2007). Indeed, those who do so may take pleasure in seeing the blame for authoritarianism fall exclusively on the shoulders of neoliberal theory and practice, even though they too endorse a form of governance and the administration of the state apparatus that does away with the people.

When individuals' relationships evolve in the absence of the people and of laws to protect against despotic and abusive power, an increase in illiberal and antidemocratic forms of resistance to 
neoliberal policies can only be expected (Gill, 1995; Hickel, 2016). As Locke, (1679 (1960): II, p. 225) put clearly:

Great mistakes in the ruling part, many wrong and inconvenient Laws, and all the slips of human frailty will be born by the People, without mutiny or murmur. But if a long train of Abuses, Prevarications, and Artifices, all tending the same way, make the design visible to the People, and they cannot but feel, what they lie under, and see, whither they are going; 'tis not to be wonder'd, that they should then rouze themselves, and endeavour to put the rule into such hands, which may secure to them the ends for which Government was at first erected.

If we accept that (a) impoverishment and inequality are on the increase; (b) governments are refusing to provide political remedies for this impoverishment; (c) and citizens' political choices are being neglected in a long series of abuses, it is not surprising that voiceless citizens may try to put the ruling power into illiberal hands that will achieve the purpose for which government was first established: securing the common public good. Under the neoliberal transformation of private rules into public rules, citizens are witnessing a continuous disregard for their collective well-being (see the relationship between the election of Donald Trump and the deteriorating life conditions of American citizens living in the rust belt states of Michigan, Pennsylvania and Wisconsin; Walley, 2017).

Instead of welcoming populist reactions, however, we should be clear that the anti-liberal and antidemocratic hijacking of the citizens' revolt against neoliberalism in no way respects the need for public rules. A call for the establishment and protection of public law is a call for personal and institutional liberal and democratic sovereignty, which differs fundamentally from populism and the neoliberal model of sovereignty (Dean, 2015; Foucault, 2008). This claim also rejects the political (and nightmarish) choice between neoliberalism and populism. Indeed, even if the relationship between liberal democracy and populism deserves investigation of its own, liberal and democratic sovereignty does away with the distinction between the pure and homogenous people against corrupt and homogenous elites. It also rejects the idea of the personal and benevolent leader/ protector, who bases their power on direct, unmediated, and institutionalized relationships with unorganized followers.

First, although the distinction between corrupt elites and the pure people rightly points to the problem of the legitimacy of the rulers' power, the people is not a homogeneous or pure body, whatever the criterion of belonging (ethical, ethnic, racial, economic). Far from referring to an undifferentiated and homogeneous corpus, the people is a heterogeneous political body, which includes gender, racial, and economic differences (along with disagreement about personal and collective ends), and which ultimately entails non-alienable individual rights and duties (Locke, 1679 (1960); Kant, 1793 (1977); Sieyes, 1789 (1989)).

Second, the solution to this gap is not its elimination through the immediate relationship between the leader and the pure, homogeneous people. In the liberal political tradition, there is no immediate political power. Rawls's, (1993) political liberalism, for example, points to the gap between the political principles of society (e.g., the principles of justice), which are embedded in its basic political institutions (e.g., constitutions) and in "executive" institutions (parliaments, courts, governments), and the individuals in everyday life. Accordingly, the sovereignty of the people ultimately means that, whether at the political, local, national, international, or global level, citizens' relationships are always mediated by law embedded in their public institutions (Locke, 1679 (1960); Kant, 1793 (1977); Rawls, 1993).
Even if there are many points of ideological disagreement concerning the concept of the people, sparked mainly by its use by controversial figures from the standpoint of liberalism, such as Rousseau's concept of the general will, in Locke's and Kant's political philosophy the sovereignty of the people does not mean that the people can pursue its immediate and unbridled wishes. A charter of rights or constitutional principles always binds the will of the people (Locke, 1679 (1960); Kant, 1793 (1977)). In the absence of such restrictions, the people can itself become a despot, a danger which has been acknowledged since at least the time of Aristotle, (2002; see also Cicero 1999; Locke, 1679 (1960); Rawls, 1971, 1993).

Third, in Locke's and Kant's political philosophies, the protective role of the people aims to ensure a political society of free and equal persons, not a society of minor and inferior subjects who need benevolent protectors, such as populist leaders (see Locke's claim concerning the constitutional protection of individuals' political rights (Locke, 1679 (1960)) and Kant's rejection of paternalistic and despotic political power (1793 (1977)).

Liberal theory challenges the underlying neoliberal and populist Manichean opposition between personal interests and the general will of the people ("either there is a general will or individual liberty is repressed", "if there is individual liberty, the general will is excluded"). If, when protecting the homogenous people against corrupt elites, populists endorse the first alternative, and if the neoliberal exclusion of the people corresponds to the second, both approaches remain blind to the political responsibility of free persons. Ultimately, whether by imposing on others the unrestrictedly and selfish pursuit of wellbeing or by appealing to the unlimited will of the people, both undermine individuals' political freedom.

For these reasons, personal and institutional liberal and democratic sovereignty is more than a childish claim to state protection against political irresponsibility and blindness to public contributions to individual private well-being. It is a claim to one's own political responsibility, for oneself and others, as this claim is clearly formulated in Locke's and Kant's political philosophies.

The social safety net. Although Locke's and Kant's political philosophies do not require individuals under public law to positively foster others' social, economic and cultural well-being, their perspectives on the public challenge indifference towards the increasing poverty and inequality that we are currently witnessing under neoliberalism (Greer, 2014; Stiglitz, 2013). They also speak against the state authoritarianism that neoliberalism engenders (Brown, 2015; Bruff, 2014; Kreuder-Sonnen and Zangl, 2015; Orphanides, 2014; Schmidt and Thatcher, 2014). Of course, we may disagree on the extent of the success or failure of Locke's and Kant's theoretical political constructions of a political personality, understood in analogy with a single body. Some criticize the illiberal nature of Kant's general will (for example the representatives' betrayal of the people's interest in the liberal social contract; Badiou, 2016). Nevertheless, these weaknesses challenge neither individual liberty, nor the people, nor the inter-protective role of the people and public law. Indeed, they remind us of the political meaning of 'the body politic'.

Despite their strong commitment to the protective role of the people, along with their awareness of our political responsibility for the fairness of the public rules that affect us all, Locke and Kant do not fully explain the necessity of the notion of the people when it comes to producing a social safety net created by the will of the sovereign people. They also do not consider democratic procedures for arriving at collective support for a social safety 
net. With the differences between ancient and modern democracies acknowledged (Bobbio, 1988), the fact that Locke and Kant endorse democracy's core feature, the existence of a people (the entire body of citizens) with a right to make collective decisions (Bobbio, 1988), does not make them democrats, at least in our modern sense (Bobbio, 1988).

Following our premises, and acknowledging the various ways in which globalization impacts states and people, democratic governments should establish democratic procedures at the national and international level to secure collective support for the political and social safety net. These include public laws based on the will of the people that provide each person with a unique set of liberties with regard to the use of material goods which impose on each a unique set of restrictions. These liberties and restrictions will ensure that individuals have an equal coercive power to prevent their becoming servile persons and, correlatively, to prevent any one of them from becoming a despotic lord. They also require the assumption of the cooperative nature of individual well-being, and therefore the pursuit of social justice with regards to the fruits of that cooperation. The political translation of the common right to the results of social cooperation through public policies that protect social rights, such as the right to education and health, is also desirable. This requires the "direct or indirect participation of citizens, and the greatest possible number of citizens, in the formation of laws" (Bobbio, 1988, p. 38). Again, it is necessary to recast the political principle of provided (not purchased) services as a norm of public and social welfare. Finally, it requires awareness of the fact that in the absence of a political body to protect and enforce individual liberties, individuals will lack the personal, social and institutional resources to make use of their own liberty.

\section{Conclusion}

We have shown that neoliberalism's rejection of the existence of the people seriously harms individual private liberty and does not prevent the transformation of the majority of free individuals into servile persons. More specifically, we have shown that forbidding the public restriction of liberty (which is inherent in the concept of the people) while exclusively defending private restrictions of liberty (a) deprives the majority of citizens of the equal right of coercion, and therefore of equal liberty, and (b) promotes the rise of different political statuses, a division between those who obey and those who command. We have also shown that neoliberalism lacks the resources to prevent the total alienation of liberty.

In comparing neoliberalism to Locke and Kant's political philosophies, we have shown how the protective role of the people is compatible with individual liberty. Since it requires an equal right of coercion, it allows for the protection of individual liberty. We have also shown that this is not an exclusively collective task. It also depends on each citizen. In Locke's and Kant's political philosophies, the protective role of the people aims to ensure that political society is free and equal, not a society of minor and inferior subjects who need benevolent protectors (Locke, 1679 (1960)); Kant, (1793 (1977)). We concluded that, against neoliberalism's faith in the powers of the spontaneous order, individual political autonomy depends on the public safeguarding of liberties. We also pointed out that unless there is a political turn toward the acknowledgement of the people or peoples, along with recognition of the significance of their political deliberation, neo-liberalism cannot be separated from illiberal and antidemocratic political choices. Similarly, if individuals' relationships evolve beyond the existence of the people and lack laws to protect against despotic and abusive power, we cannot prevent the development of slavish and servile relationships among citizens. The fact that these relationships remain politically forbidden in neoliberal states, for example in the European Union, only reveals that neoliberalism's dismantling of liberal and democratic political institutions has not fully succeeded. In the absence of the people, human rights depend exclusively on individuals' interests; the spontaneous order thus cannot prevent neoliberalism from descending into slavery and serfdom, i.e., self-slavery and self-serfdom.

Future research should ascertain how, in the aftermath of neoliberalism's devastating social and political effects on public cohesion, it might be possible to reconstitute a sense of political belonging (Habermas, 2008) and the sovereignty of the people (Pyke, 2001) under globalization.

Future research should also continue to evaluate the dangerous process of what many are calling refeudalization under neoliberalism (Supiot, 2013; Szalai, 2017). It is worth comparing the feudal alienation of political liberty, for example the different perspectives on vassalage (Bloch, 1961), with contemporary forms of inferior political status.

Finally, future research could evaluate how, as a reaction to the disenchantment with the rise of bureaucracy identified by Weber, (1978), neoliberalism might express a kind of re-enchantment with the exclusively individual rational actor, who claims a nonalienable space of liberty against the bureaucratic "iron cage".

Received: 20 March 2018 Revised: 8 June 2018 Accepted: 3 July 2018 Published online: 14 August 2018

\footnotetext{
Notes

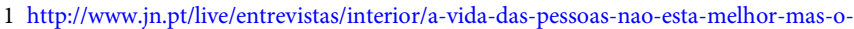
pais-esta-muito-melhor-3697968.html

2 https://www.theguardian.com/business/2015/jul/05/greece-referendum-early-resultshistoric-no-vote-against-austerity, Accessed 14 Feb.

3 https:/www.mintpressnews.com/before-the-brexit-greek-voters-said-no-to-austeritymeasures-got-more-austerity-measures/218122/; Accessed 14 Feb
}

\section{References}

Alber J (1988) There a Crisis of the Welfare State? Cross-National Evidence from Europe, North America, and Japan. Eur Sociol Rev 4(3):181-207

Aristotle (2002) The Politics (trans. Carnes Lord). University of Chicago Press, Chicago

Badiou A (2016) Twenty-Four Notes on the Uses of the Word "People". In: Allen A (ed) What is a People. (New directions in Critical Theory). Columbia University Press, New York, pp 21-31

Barro R (2009) Government spending is no free lunch: how Democrats are peddling voodoo economics. Wall Street Journal. http://www.wsj.com/articles/ SB123258618204604599 Accessed Nov 2015

Bales, K (1999) Disposable People: New Slavery in the Global Economy. University of California Press:Berkeley and Los Angeles, California and London, England

Beck U (2002) Power in the global age. Polity, Cambridge, Malden

Beetham D (1992) Liberal democracy and the limits of democratization Polit Stud Special Issue 4XL:40-53

Berlin I ((1958) [1997]) Two concepts of liberty. In: Goodin R, Pettit P (eds) Contemporary political philosophy. Blackwell Publishers, Oxford, pp 391-417

Bloch M (1961) Feudal Society: social class and political organization. The University of Chicago Press, Routledge \& Kegan Paul, London

Bobbio N (1988) Liberalism and democracy. Verso, London, New York

Boyer R, Drache D (eds) (1996) States against markets: the limits of globalization. Routledge, London

Brodie J (2007) Reforming social justice in neoliberal times Stud Social Justice 1 (2):93

Brown W (2015) Undoing the demos: neoliberalism's stealth revolution. Zone Books, Cambridge

Bruff I (2014) The rise of authoritarian neoliberalism Rethink Marx 26(1):113-129 Buchanan J, Tullock G (1962) The calculus of consent: the logical foundations of constitutional democracy. Liberty Fund, Indianapolis

Butler J (2016) "We, the People" Thoughts on Freedom of Assembly. In: Allen A (ed) What is a People. (New directions in critical theory). Columbia University Press, New York, pp 49-64 
Canovan M (1999) Trust the people! populism and the two faces of democracy Polit Stud 47:2-16

Cicero (1999) On the commonwealth and on the laws. Cambridge University Press, Cambridge, New York, Melbourne, Madrid, Cape Town, Singapore, São Paulo

Clayton R Pontusson J (1998) Welfare-State Retrenchment Revisited: Entitlement Cuts, Public Sector Restructuring, and Inegalitarian Trends in Advanced Capitalist Societies and Source World Polit 51(1):67-98

Collier R (2001) Populism. In: Smesler NJ, Baltes PB (eds) International encyclopaedia of social and behavioral sciences. Elsevier, Oxford, pp 1813-16

Dahl R (1998) On Democracy. With a New Preface and Two New Chapters by Ian Shapiro. Yale University Press, New Haven \& London

Dean J (2008) Communicative Capitalism: Circulation and Foreclosure of Politics. In: Boler M (ed) Digital Media and Democracy: Tactics in Hard Times. The MIT Press, Cambridge, Massachusetts. London, England, pp 101-121

Dean J (2015) Neoliberalism's Defeat of Democracy. Critical Inquiry. http:// criticalinquiry.uchicago.edu/neoliberalisms_defeat_of_democracy.

Elstain JB (1981) The public man, private woman: woman in social and political thought. Princeton University Press, Princeton, NJ

England K, Ward K (2016) Theorizing neoliberalization. In Springe S, Birch K, MacLeavy J (eds) The Handbook of Neoliberalism. Routledge, London, New York, pp 27-38

Esping-Andersen G (1990) The three worlds of welfare capitalism. Polity Press, Cambridge

Foucault M (2008) The birth of biopolitics. Palgrave Macmillan, New York

Freeden M (2016) After the Brexit referendum: revisiting populism as an ideology J Political Ideol 22(1):1-11

Gill R, Pratt A (2008) Precarity and cultural work in the social factory? immaterial labour, precariousness and cultural work Theory Cult Soc 25(7-8):1-30

Gill S (1995) Globalisation, market civilisation, and disciplinary neoliberalism Millenium: J Int Stud 24(3):399-423

Gill S (1998) European governance and new constitutionalism: economic and Monetary Union and alternatives to disciplinary Neoliberalism in Europe New Political Econ 3(1):5-26

Gough JW (1957) The social contract: a critical study of its development. Oxford University Press, Oxford

Gray J (1989) Essays in political philosophy. Routledge, London

Gray J (1993) Post-liberalism. studies in political thought. Routledge, London

Greer S (2014) Structural adjustment comes to Europe: lesson for Eurozone from the conditionality debates Glob Social Policy 14(1):51-71

Habermas J (2000) Crossing globalization's valley of tears New Perspect Q 17 (4):51-7

Habermas J (2008) Citizenship and National Identity. Global Justice: Seminal Essays. Vol. I. In: Pogge T, Moellendorf D (eds) Global Responsibilities. Parangon House St. Paul, St. Paul, pp 285-309

Hall S (2011) The neoliberal revolution J Cult Stud 25(6):705-728

Hartman Y (2005) In bed with the enemy: some ideas on the connections between neoliberalism and the welfare state Curr Sociol 53(1):57-73

Harvey D (2005) A brief history of neoliberalism. Oxford University Press, Oxford, New York

Hayek F (1960) The constitution of liberty. Chicago Press, Chicago and London

Hayek J (1976) Law, legislation and liberty. the mirage of social justice, Vol. II. The University of Chicago Press, Chicago, London

Hickel J (2016) Neoliberalism and the end of democracy. In: Springer S, Birch K, MacLeavy J (eds) 2016. The Handbook of Neoliberalism. Routledge, London, New York, pp 142-152

Homer (1996) The Odyssey (trans. by Robert Flages). Viking, New York

Kant I (1793) [1977]) Über den Gemeinspruch: Das mag in der Theorie richtig sein, taugt aber nicht für die Praxis. In: Weischedel W (ed) Werke in Zwölf Bänden Band XI 1977. Suhrkamp Verlag, Frankfurt am Main, pp $125-172$

Kersting W (1992) Politics, freedom, and order: Kant's political philosophy. In: Guyer P (ed) The Cambridge Companion to Kant. Cambridge University Press, New York, pp 341-368

Klein N (2007) The shock doctrine: the rise of disaster capitalism. Allen Lane, London

Kreuder-Sonnen C,Zangl B (2015) Which post-Westphalia? International organizations between constitutionalism and authoritarianism Eur J Int Relat 31 (3):568-594

Krugman P (2012) Europe's austerity madness. The New York Times. http://www. nytimes.com/2012/09/28/opinion/krugman-europe-austerity-madness.html Accessed Mar 2017

Lane J-E (2006) Law and Politics: Reflections upon the concept of a spontaneous order and the EU. In: Kurild-Klitgaar, Koppl P, Birner J (eds) Advances in Austrian Economics, Vol. 8. The Dynamics of Intervention: Regulation and Redistribution in the Mixed Economy. Elsevier, Amsterdam, pp 429-440

Legido-Quigley H, Karanikolos M, Hernandez-Plaza S, Freitas C, Bernardo L, Padilla B, SáMachado R, Diaz-Ordaz Ka Stuckler D, McKee M (2016) Effects of the financial crisis and Troika austerity measures on health and health care access in Portugal Health Policy 120(7):833-839

Kus B (2006) Neoliberalism, Institutional Change and the Welfare State: The Case of Britain and France Int Comparative Sociol 47(6):488-525

LeBaron G (2008) Captive Labour and free market; prisons and production in USA Capital Class 32(2):59-81

Locke J (1679 [1960]) Two Treatises of Government. In: Laslett P (ed) Cambridge texts in the history of political thought. Cambridge University Press, Glasgow

Lorenz C (2012) If You're So Smart, Why Are You under Surveillance? Universities, Neoliberalism, and New Public Management Crit Inq 38(3):599-629

MacLeavy J (2016) Neoliberalism and Welfare. In: Springer S, Birch K, MacLeavy J (eds) The handbook of neoliberalism. .Routledge, London, New York, pp 252-261

MacRae D (1969) Populism as an ideology. In: Ionescu G, Ernst GR (eds) Populism: its meaning and national characteristics. Macmillan Company, London, pp 153-165

Marshall T (1950) Citizenship and social class. In: Goodin R, Pettit P (eds) Contemporary political philosophy. Blackwell Publishers, Oxford

Marx K (2000) Karl Marx: selected writings. In: David McLellan (ed) Oxford University Press, Oxford, New York

McCluskey M (2003) Efficiency and social citizenship: challenging the neoliberal attack on the welfare state Indiana Law J 78(2):783-876

Mendes P (2003) Australian neoliberal think tanks and the backlash against the welfare state. J Australian Polit Econ 51:29-56.

Miller D (2000) Citizenship and National Identity. Polity, Cambridge

Morgan E (1988) Inventing the People. WWW Norton

Morris C (2000) The very idea of popular sovereignty: "we the people" reconsidered Soc Phil Policy Foundation 17(1):1-26

Mudde C,(2004) The Populist Zeitgeist Gov Oppos 39(4):541-63

Mudde (2013) Populism. In: Freeden M Sargent L T Stears M (eds) The Oxford Handbook of Political Ideologies. Oxford University Press, Oxford, pp 493-512

Mudde C Kaltwasser C (2013) Exclusionary vs. inclusionary populism: comparing contemporary Europe and Latin America Gov Oppos 48(2):147-174

Mudge S (2008) The state of the art. What is neoliberalism? Socio-Econ Rev 6:703-731

Nozick R (1974) Anarchy, State, and Utopia. Blackwell, Oxford

Orphanides A,(2014) The Euro Area Crisis: Politics over Economics Atl Econ J 42:243-263

Overbeek A (eds) (1993) Restructuring hegemony in the global political economy The rise of transnational nep-liberalism in the 1980s. Routledge, London, New York

Peters M (2016) Education, neoliberalism, and human capital: homo economicus "as entrepreneur of himself". In: Springer S, Birch K, MacLeavy J (eds) The Handbook of Neoliberalism. Routledge, London, New York, pp 297-307

Pyke J (2001) Globalization: The Bane of Popular Sovereignty. In: Charles J. Round $\mathrm{T}$ (eds) Beyondthe Republic; Meeting the Global Challenges to Constitutionalism 2001. Federation Press, Leichhardt, N. S. W., pp 205-2014.

Queiroz R (2016) Neo-liberal TINA: an ideological and political subversion of liberalism Crit Policy Stud 10(4):1-20

Queiroz R (2017) From the exclusion of the people in neoliberalism to publicity without a public Pal Commun 34(2):1-11

Raddon M-B (2008) Neoliberal legacies: planned giving and the new philantropy Stud Political Econ 81:27-48

Ramey J (2015) Neoliberalism as a political theology of chance: the politics of divination Pal Commun 1:1-9

Rawls J (1971) A theory of justice. Oxford University Press, Oxford

Rawls J (1993) Political liberalism. Columbia University Press, New York

Rawls J (1999) The Law of Peoples, with "The Idea of Public Reason Revisited". Harvard University Press, Cambridge, Massachusetts. London, England

Read J (2009) A genealogy of homo-economicus: neoliberalism and the production of subjectivity Foucault Stud 6:35-36

Rhodes M (1996) Globalization and west European welfare states: a critical review of recent debates J Eur Soc Policy 6(4):305-27

Rousseau JJ (1762) Du Contrat Social. Gallimard, Paris, [1964]

Schneider J, Schneider P (2007) Mafias. In: Nugent D, Vincent J (eds) A Companion to Anthropology of Politics. Blackwell Publichers, Malden, Oxford, pp 303-317

Schmidt V,Thatcher M,(2014) Why are neoliberal ideas so resilient in Europe's political economy? Crit Policy Stud 8:340-347

Sieyes EJ ([1789] (1989)) Qu’est ce que le Tiers État, Precedé de L’Essai sur les Privilèges. PUF, Paris

Stiglitz J (2013) The price of inequality. Penguin Books, London

Stiglitz J (2016) The Euro: And Its Threat to the Future of Europe Price of Inequality. Allen Lane, Penguin Books, London

Supiot A (2013) The public-private relation in the context of today's refeudalization I CON 11(1):129-145

Szalai E (2017) Refeudalization. Corvinus J Sociol Soc Policy 8(2):3-24 
Taylor (1979) What' Wrong With Negative Liberty?. In: Goodin R, Pettit P (eds) Contemporary Political Philosophy. Blackwell Publishers, Oxford, pp 418-428

Wacquant L (1999) How penal common sense comes to Europeans Eur Soc 1 (3):319-352

Walley C (2017) Trump's election and the "white working class": What we missed Am Ethnol 44(2):231-236

Weber M (1978) Economy and society: an outline of interptretative sociology. University of California Press, Berkeley, Los Angeles

Weyland K (1999) Neoliberal populism in Latin America and Eastern Europe Comp Polit 31(4):379-401

Weyland K (2001) Clarifying a contested concept. populism in the study of Latin American Politics Comp Polit 34(1):1-22

Whiteside $H$ (2016) Neoliberalism as austerity: the theory, practice, and purpose of fiscal restraint since 1970s. In: Springer S, Birch K, MacLeavy J (eds) The Handbook of Neoliberalism. Routledge, London, New York, pp 361-369

Williams H (1994) Kant on the social contract. In: Boucher D, Kelly P (eds) The Social Contract from Hobbes to Rawls 1994. Routledge, London, New York, pp 132-146

Wilson K (2012) Race, racism, and development: interrogating history, discourse and practice. Zed Books, London, New York

\section{Data availability}

All data analyzed is included in the paper.

\section{Additional information}

Competing interests: The author declares no competing interests.

Reprints and permission information is available online at http://www.nature.com/ reprints

Publisher's note: Springer Nature remains neutral with regard to jurisdictional claims in published maps and institutional affiliations.

\section{(c)}

Open Access This article is licensed under a Creative Commons Attribution 4.0 International License, which permits use, sharing, adaptation, distribution and reproduction in any medium or format, as long as you give appropriate credit to the original author(s) and the source, provide a link to the Creative Commons license, and indicate if changes were made. The images or other third party material in this article are included in the article's Creative Commons license, unless indicated otherwise in a credit line to the material. If material is not included in the article's Creative Commons license and your intended use is not permitted by statutory regulation or exceeds the permitted use, you will need to obtain permission directly from the copyright holder. To view a copy of this license, visit http://creativecommons.org/ licenses/by/4.0/.

(C) The Author(s) 2018

\section{Acknowledgements}

I am grateful to Carolyn Benson for the literary review. 